\title{
Research on the Innovation of College Art Talents Training Mode Under the Background of Sino- Russian Cooperation*
}

\author{
Feng Qi \\ Heihe University \\ Heihe, China 164300
}

\author{
Zhongfeng $\mathrm{Fu}$ \\ Heihe University \\ Heihe, China 164300
}

\begin{abstract}
Heihe city is located in the Sino-Russian frontier of education exchange, with geographical advantages richly endowed by nature. Relying on the geographical advantages, Heihe University implements the Sino-Russian joint education to cultivate art talents. The university has been continuing to expand the school opening up, the introduction of Russian advanced educational philosophy and educational resources, finally forming an educational path of characteristic talents of art. Combined with Chinese and Russian colleges and universities and art creation units, the creative training mode of "one class of the two countries" aimed at off-campus practical education for Chinese and Russian Art majors will be cofounded.
\end{abstract}

Keywords-China and Russia; colleges and universities; art talents; training model

\section{INTRODUCTION}

Through the comparison of the training modes of Chinese and Russian art talents in the aspects of educational culture background, teaching idea and teaching mode, this paper makes a deep study on how to continue exploring the training mode of art talents under the background of Sino-Russian joint school-running cooperation, and develops the mode more in line with its own characteristics, which is a frontier for the construction of a joint school-running cooperation between China and Russia. The training mode of fine arts talents with outstanding pioneering, intensive knowledge and optimized characteristic teaching links is of great significance. It is also of strategic necessity for the two countries to realize the sustained, healthy and rapid development of cooperative school-running education.

\section{BACKGROUND OF SINO-RUSSIAN COOPERATION IN RUNNING SCHOOLS}

As a powerful country of culture and art, Russia is at the top of the list in the whole world in both theoretical research and practical research of fine arts. Its educational ideology, system, standards, contents and methods are highly praised for having nurtured a number of masters of fine arts, which has exerted a great influence on the world, especially on the art

*This paper is the phased research result of the special project of Heilongjiang Education Science Research Base, project number: GJE1214020 education of New China, which can be said to have played an exemplary and mother-parent role.

Heilongjiang Province, as a border area with Russia, has the geographic advantage of cooperating with Russia in running schools. In order to meet the needs of social development, Heilongjiang Province has had a long history of cooperating with Russia in running schools. In the early days of the founding of the People's Republic of China, the main way to run cooperative schools was to train Russian-speaking professionals. The Russian Groups of the Third Branch of the People's Counter-Japanese Military and Political University of China, established in Heilongjiang Province, is the predecessor of Heilongjiang University, and the Northeast Agricultural University once opened a Russian research course. Ninety-six percent of the graduates chose to stay at their Alma Mater to be engaged in translating and publishing a large number of professional teaching documents and textbooks of agricultural universities in the former Soviet Union for the new China at that time. Then, these books became the textbooks of agricultural colleges and universities all over the country. Since 1986, Heihe University, Qiqihar University, Northeast Agricultural University and other universities in Heilongjiang Province have been cooperating with Russia. So far, 19 universities in Heilongjiang Province have cooperated with Russia in running schools, and a total of 81 related specialties have been set up.

However, with the warming up of Sino-Russian relations and the impact of contemporary art education and teaching reform, higher requirements have been put forward for art education and talent training in colleges and universities. In addition, the development of market economy, the change of social environment and the adjustment of employment system in our country have led to the change of the requirements for the training of art professionals in colleges and universities. In the context, the innovative reform of the training mode of applied talents is imminent.

Under the background of Sino-Russian cooperation, it is particularly important to continuously explore and develop a talent training model that is more in line with the characteristics of Heilongjiang universities, and explore how to make the trained talents have strong competitiveness. This requires in-depth excavation and research on the teaching 
methods, methods, ideas and resources of Sino-Russian cooperation on the basis of the original school-running model. At the same time, it's necessary to constantly innovate the training mode of application-oriented talents with characteristics, improve the quality of practical teaching links, and form a practical teaching system of fine arts with the features of Sino-Russian cooperation in running schools among colleges and universities of Heilongjiang Province.

\section{ORIENTATION OF ART TALENTS TRAINING IN SINO- RUSSIAN JOINT SCHOOL}

The concept of Sino-Russian joint education of art talents is extended to four "bases" guiding the talent training experiments.

\section{A. Majors Should Be Set Up According to Market Demand}

In cooperative school-running, majors should be set up according to market demand by taking advantage of Heihe geographical advantages that lies on the border between China and Russia, seizing the opportunity of vigorous development and communication and cooperation with Russia, so as to enable students to personally feel the Russian painting style and characteristics deeply, and to make use of them in their future art creation, so that, their own creative styles can be shaped.

\section{B. Setting Courses Based on Professional Requirements}

According to professional requirements, referring to training objectives, it's crucial to adjust the proportion of quality courses, backbone courses and professional core competence courses as well as the relationship between content and structure to highlight the teaching of art drawing practice courses, strengthen the training of applied creative ability, finally narrowing the distance between training and demand.

\section{Practicing Skills of Painting According to the Standard}

It's necessary to stress the professional skills training according to the characteristics of the art major. Especially in the practice of graduation art, the traditional way should be abandoned. It's wise to go to the field for graduation creation and solve practical problems, which is helpful for improving students' practical and innovative ability. It will be better for the university to employ Russian experts and professors to serve as teachers in the teaching of art courses for students in the experimental area, providing comprehensive guidance for theoretical and practical teaching.

\section{Testing the Quality According to the Social Evaluation}

The evaluation of professional training quality standards tend to be finally manifested in "talent products". The ability to withstanding the social test is the ultimate yardstick to test the quality of teaching.

\section{THOUGHTS ON THE CONSTRUCTION OF TEACHING SYSTEM FOR THE CULTIVATION OF ART TALENTS IN COLLEGES AND UNIVERSITIES UNDER THE BACKGROUND OF SINO-RUSSIAN COOPERATION}

\section{A. Practical Curriculum System with Outstanding Characteristics}

The key to embodying the advantages of Sino-Russian cooperation in running schools lies in the establishment of a curriculum system that conforms to the characteristics of SinoRussian cooperation in running schools, which requires the introduction and development of Russian fine arts education teaching resources and artistic styles in terms of curriculum setting, curriculum implementation, curriculum content, curriculum resources and teaching methods to improve its own curriculum system and widen the thinking of educational and teaching reform. On the basis of courses that generally reflect Russian characteristics, such as Russian human body, Russian landscape creation and Russian basic composition, Russian paper carving, Russian ceramics and Russian folk arts and crafts should be added to realize the construction of a distinctive and scientific and rational curriculum system. On the basis of perfecting the compulsory courses, it's essential to introduce courses with Russian cultural characteristics to enrich the types of elective courses and form a system of innovative and practical courses for the cultivation of applied art talents with distinctive features, so as to stimulate students' enthusiasm for learning and highlight the characteristics of Sino-Russian cooperation in running schools. These measures are pretty conducive to the cultivation of students' artistic accomplishment and comprehensive quality.

\section{B. Practical Textbook System with Distinct Characteristics}

The construction of a perfect textbook system is an important supporting condition for the buildup of the curriculum system. The introduction of high-quality Russian original textbooks and the compilation of textbooks by SinoRussian cooperation are two effective forms for the establishment of a textbook system with unique features of Sino-Russian cooperation in running schools. By introducing the most advantageous course textbooks such as sketch and oil painting in Russia, the University shall compile characteristic textbooks based on its own reality. In addition, Russian teachers can be invited to participate directly in the compilation of practical teaching materials. Moreover, by compiling works, publishing picture albums and works collection and other forms, a perfect practical teaching material system for Russian cooperative education can be established. Then, it's wise to research and explore a practical teaching material system with innovative value followed by promoting and using it among similar universities, so as to stimulate the extension of universities and colleges' art achievements in Heilongjiang of cooperative education with Russia.

\section{Practical Teachers with High Quality and Characteristic}

It is necessary to establish and maintain relatively stable foreign practical teacher resources with a certain scale, and further adjust them dynamically. At the same time, Russian meritorious painters, artists and research experts of higher art 
education and teaching with senior professional and technical ability can be introduced to realize the resource sharing of teachers. In addition, it's important to pay attention to training young backbone teachers. In order to improve the practical level of young backbone teachers, their overall level should be improved by going to Russian universities for academic exchanges, short-term learning, visits and other forms. On this basis, a research team with high research level, strong scientific research strength and distinct characteristics of China and Russia is expected to be established, so as to set up a research team of strong specialty with Chinese and Russian hues and promote the integral improvement of practical teaching level.

\section{Promoting the Integration of Industry-university-research Cooperative Education}

Relying on the characteristic art practice teaching bases of Heilongjiang, it's advisable for China and Russia to sign cooperation agreements with universities and artists associations in the Far East and central regions of Russia, and some other regions of Russia. It will be meaningful to invite Russian meritorious painters, artists and university teachers to serve as practical teaching instructors in various specialties, highlighting the advantages of the practical links of running schools with Chinese and Russian characteristics, taking practical teaching as an extension of classroom teaching, so that students can truly understand the process of Russian practical teaching. By this way, the role of practical teaching in assisting classroom teaching can be played well, which helps to improve students' practical ability. Finally, it will establish a new system of practical teaching with innovative value under the framework of Sino-Russian cooperation in line with its own characteristics. To carry out research and development of practical teaching projects in Russian and provincial universities, it's important to promote the popularization and application of teaching research results, perform counterpart support between China and Russia, between regions and between schools. In the meantime, for colleges, they should shoulder the responsibility to train talents for society and universities to realize resource sharing and promote the integration of industry-university-research cooperative education.

\section{THE FACTORS THAT CAN BE UTILIZED BY ART TALENTS IN SINO-RUSSIAN JOINT UNIVERSITIES}

According to philosophy, the cultivation of talents is the result of the interaction of internal and external factors.

\section{A. The External Cause of Talent Cultivation Needs Three Elements, Namely, Good Timing, Geographical Convenience, and Good Human Relations}

The so-called timing is that the training of art talents jointly run by China and Russia is in line with the current international situation, and from the perspective of the boundlessness of educational and teaching resources, learning Russian art conforms to the current national conditions of our country, that is, China and Russia should be friendly for generations, mutually beneficial and mutually beneficial. Establishing such a painting system with strong Russian artistic style and characteristics is the most basic condition for art exchange between China and the outside world. The socalled geographical convenience means that the regional environment should meet the environmental requirements of education and teaching. Heihe is located in the unique position of the border between China and Russia. Compared with the specialties of other similar art colleges, it provides the best geographical environment for learning Russian art. The socalled "favorable human relation" demands good faculty. Heihe University embraces excellent oil painting education and teaching experts of Russia, which is great significance for students to learn Russian traditional and modern art styles and establish Russian art research and related art research and creation system. Therefore, Heihe enjoys the best external conditions for training Russian oil painting talents.

\section{B. The Internal Cause of Talent Cultivation Is Students}

The law of dialectical relationship between internal and external causes is the law of talent cultivation that shall be followed in the construction of experimental areas. Through experimental teaching system, it's not so hard to guide and educate students to gradually master the basic skills of oil painting from perceptual knowledge, and through continuous strengthening, eventually rising to rational thinking and achieving our goal of talent cultivation.

\section{The Training Program of Art Talents In SinO- RUSSIA JOINT SCHOOL}

- The imported foreign courses account for more than one third of all courses and core courses in Sinoforeign cooperatively-run schools. There are 57 courses in the teaching plan, of which 19 are introduced from Russia, accounting for $33.3 \%$ of the total number of courses. Introduced Russian curriculum names are: still life sketch, gypsum sketch, colorful still life, decorative pattern, figure sketch, anatomy, watercolor still life, oil painting landscape creation, figure head sketch, bust sketch, human body sketch, still life of oil painting, head of oil painting, bust of oil painting, human body of oil painting, whole body portrait of oil painting, Russia folk art, Russian architectural design, Russian ceramic art (figure sketch courses often employ Russian models).

- Teachers in foreign educational institutions are responsible for more than one third of all teaching hours in Sino-foreign cooperatively run schools. The total teaching hours are 2965, of which Russian teachers take 1278 , accounting for $43.1 \%$ of the total teaching hours.

- Faculty. There are 16 Chinese teachers, including 2 professors, accounting for $12.5 \%$ of the total number of Chinese teachers, 6 associate professors, accounting for $37.5 \%$ of the total number of Chinese teachers, and 5 lecturers, accounting for $31.25 \%$ of the total number of Chinese teachers. There are 6 long-term Russian teachers, including one professor, accounting for $16.7 \%$ of the total number of Russian teachers, 4 associate professors, accounting for $66.7 \%$ of the total 
number of Russian teachers, and 1 lecturer, accounting for $16.7 \%$ of the total number of Russian teachers. In addition, every semester, according to the needs of the curriculum. Besides that, Foreign teachers from Russia are invited to teach at irregular intervals. Russian teachers account for $37.5 \%$ of the total number of teachers in China and Russia.

- Selection of teaching materials. Russian textbooks account for $38.5 \%$ of the total textbooks and most of the courses undertaken by Russian teachers use Russian textbooks, some of which are new editions of Russian textbooks. In teaching, some Russian teachers use self-compiled handouts and Russian visual textbooks, which occupy a certain proportion as supplementary books.

\section{SINO-RUSSIAN JOINT SCHOOL-RUNNING AIMS TO TRAIN COMPOUND ART TALENTS}

Joint education between China and Russia should cultivate artistic talents with innovative consciousness, innovative thinking and innovative personality with the training objectives of "specifications + characteristics" and "quality + ability" of the composite art talents. During the running, "one specialty and multi-abilities" training mode should be implemented. Taking Heihe University as an example, the cultivation of art talents needs continuous exploration and development. It's indispensable for the university to continue to explore the teaching methods of Sino-Russian cooperation on the basis of the original $2+2,3+1$ joint education.

On the basis of absorbing the successful experience of the training mode of foreign art talents, especially Russian art talents, it's important to optimize the cultivation of compound art talents in the light of the reality of our "showing outstanding frontiers with wide range of knowledge scope and characterizing with intensive knowledge", and put forward corresponding countermeasures and suggestions to change the long-term comparatively single state of talents distinction between "specialty" and "communication" to fill in the gaps of talent types and promote the development of higher education personnel training to step into the direction of diversification and multi-adaptability, which has the characteristics of strong operability.

It's essential to train professional artists with Russian painting style and characteristics, so that they can better grasp the characteristics of Chinese and Russian art and the basic characteristics of East and West figures. These talents should have a solid foundation in modeling, a strong foundation in fine arts, and a better ability to use art language to create paintings of the times. At the same time, they should systematically grasp the broad theoretical basic knowledge in the field of their specialties equipped with strong self-study ability, innovative consciousness and high comprehensive quality.

Under the background of Sino-Russian joint schoolrunning, the construction of an advanced, knowledge-intensive and featured teaching mode of compound art talents cultivation proves the scientificity of subject education, adapting to the trend of social and economic development for the demand of cross-compound talents, and promoting the enthusiasm of "teaching" and "learning".

\section{CONCLUSION}

By virtue of the high-quality resources in art education of colleges and universities and the construction of featured specialties and key specialties, it is available to promote formulating such a teaching and practical training condition, curriculum system and teaching content reform and teachers team as reaching the international advanced level, drive formulating a teaching, training, and high-level personnel cultivation and employment integrated opening and sharing internship and practice training studio group for cultivating Chinese and Russian art talents, establish an effective mechanism for the introduction, training and management of Chinese and Russian full-time and part-time teachers, create such a shared comprehensive resource library of art education talents in colleges and universities as participated by industrial enterprises and Chinese and Russian outstanding experts and with Sino-Russian higher art education characteristics; in addition, it is also available to get art specialty in colleges and universities in China and Russia generating a clustered effect in teaching reform, social service and radiated driving and other aspects, deepen internal management mechanism reform and establish a perfect Sino-Russian characterized talent cultivation quality assurance system so as to promote constructing a new-type college art talent cultivation mode under the background of Sino-Russian cooperation and provide a successful example for similar colleges and universities in seeking for Sino-foreign cooperation development and talent cultivation.

\section{REFERENCES}

[1] Fu Zhongfeng, Qin Siying. Research on the Practical Teaching System of Fine Arts in Heilongjiang Colleges and Universities under the Background of Sino-Russian Cooperation [J].Art Education,2015,03. (in Chinese)

[2] Zhang Xiaoli. Development and Utilization of Russian Art Resources in Art Education in Northern Universities [J].Art Education Research,2012,09. (in Chinese) 